\title{
PELAKSANAAN PROGRAM \\ TANGGUNG JAWAB SOSIAL DAN LINGKUNGAN PERUSAHAAN DI KABUPATEN PROBOLINGGO
}

\author{
Mohammad Awaludin \\ STIH Zainul Hasan Kraksaan, Probolinggo \\ Email : mohammadawaludin654@gmail.com
}

\begin{abstract}
Abstrak
Tujuan dari penelitian ini adalah untuk menjelaskan peran, fungsi dan tanggungjawab FKTSP dalam pelaksanaan program TJSL di Kabupaten Probolinggo, serta menjelaskan faktor pendukung dan penghambat dalam pelaksanaan tugasnya. Desain penelitian yang dipakai adalah deskripsi kualitatif. Subjek penelitian ini adalah Kabag Perekonomian Bappeda Kabupaten Probolinggo, kemudian Ketua FKTSP Kabupaten Probolinggo, serta Unit Pelaksana CSR PT POMI Kabupaten Probolinggo. Kemudian dalam penelitian ini peneliti menggunakan 2 sumber data, yaitu sumber data primer berupa hasil wawancara dan sumber data sekunder yang diantaranya perundang-undangan tentang TJSL, dokumen, laporan FKTSP Kab Probolinggo dan lain sebagainya. Sementara teknik pengumpulan yang digunakan adalah wawancara, observasi lapangan, dan dokumentasi. Analisis data penelitian menggunakan tiga tahap yaitu, reduksi data, penyajian data dan penarikan kesimpulan/verifikasi. Pengujian keabsahan data menggunakan teknik triangulasi sumber. Hasil penelitian menunjukkan bahwa peran, fungsi dan tanggungjawab FKTSP Kabupaten Probolinggo adalah sebagai media pembangun dan pengembangan jejaring kerjasama dengan stakeholder pelaksanaan TJSL di Kabupaten Probolinggo, baik yang bersifat regional maupun nasional. Selain itu melakukan sinergitas dan harmonisasi kegiatan yang telah direncanakan baik diantara perusahaan maupun dengan pemerintah daerah. Selanjutnya faktor pendukung pelaksanaan TJSL diantaranya semangat dan komitmen anggota FKTSP; instrumen hukum yang memadai; kemajuan teknologi dan informasi; serta kesadaran masyarakat dalam upaya peningkatan kesejahteraan hidup. Semantara untuk faktor penghambat diantaranya: aturan dan kondisi perusahaan itu sendiri; dukungan teknis oleh pihak pemerintah daerah yang kurang optimal; pandemi covid-19; dan mindset masyarakat yang selama ini masih menganggap bahwa progam TJSL adalah program bagi-bagi duit.
\end{abstract}

Kata kunci: Program TJSL Perusahaan

\begin{abstract}
The purpose of this study is to explain the roles, functions and responsibilities of FKTSP in the implementation of the CSR program in Probolinggo Regency, as well as to explain the supporting and inhibiting factors in carrying out their duties. The research design used is a qualitative description. The subjects of this study were the Head of the Bappeda Economics Division of Probolinggo Regency,
\end{abstract}




\section{Zurnal Negara dan $\mathcal{X}$ eadilan \\ p-ISSN 2302-7010 e-ISSN 2721-9801}

then the Head of the Probolinggo Regency FKTSP, and the CSR Implementation Unit of PT POMI Probolinggo Regency. Then in this study the researchers used 2 data sources, namely primary data sources in the form of interviews and secondary data sources including legislation on TJSL, documents, FKTSP reports in Probolinggo Regency and so on. While the collection techniques used are interviews, field observations, and documentation. Analysis of research data uses three stages, namely, data reduction, data presentation and drawing conclusions/verification. Testing the validity of the data using source triangulation techniques. The results showed that the role, function and responsibility of FKTSP Probolinggo Regency is as a medium for building and developing a network of cooperation with stakeholders in the implementation of TJSL in Probolinggo Regency, both regionally and nationally. In addition, synergize and harmonize activities that have been planned both between companies and with local governments. Furthermore, the supporting factors for the implementation of TJSL include the enthusiasm and commitment of FKTSP members; adequate legal instruments; advances in technology and information; and public awareness in an effort to improve the welfare of life. Meanwhile, the inhibiting factors include: the rules and conditions of the company itself; suboptimal technical support by the local government; covid-19 pandemic; and the mindset of the people who so far still think that the CSR program is a moneysharing program.

Keywords: Programe, TJSL,company

\section{PENDAHULUAN}

Sudah menjadi tanggungjawab negara/pemerintah secara penuh untuk mensejahterakan rakyatnya baik dibidang ekonomi maupun sosial. Tanggungjawab negara/pemerintah dalam mengatur rumah tangganya sendiri dilakukan dengan maksud dan tujuan untuk melindungi segenap bangsa Indonesia dan seluruh tumpah darah Indonesia dan memajukan kesejahteraan umum, mencerdaskan kehidupan bangsa sesuai dengan isi pembukaan Undang-Undang Dasar Negara Republik Indonesia (UUD RI) 1945 . $^{1}$

Akan tetapi negara/pemerintah jelas tidak akan mampu melaksanakan itu semua sendiri mengingat keterbatasan dana yang dimiliki, sehingga dalam hal ini negara/pemerintah harus melibatkan seluruh lapisan di masyarakat dalam melaksanakan amanat konstitusi tanpa terkecuali perusahaan/korporasi/ BUMN/ BUMD dan lain-lain agar tujun negara yang termaktub dalam pembukaan UUD 1945 dapat terwujud.

Tanggungjawab Sosial dan Lingkungan Perusahaan (TJSL) merupakan salah satu kewajiban yang harus dilaksanakan oleh perusahaan sesuai dengan isi Pasal 74 Undang-Undang Perseroan Terbatas (UUPT) yakni UU Nomor 40 Tahun 2007. Melalui undang-undang ini industri atau korporasi-korporasi wajib untuk melaksanakanya, tetapi kewajiban ini bukan suatu beban yang memberatkan. Hal ini mengingat bahwa proses pembangunan suatu negara bukan hanya tangungjawab pemerintah dan industri saja, tetapi setiap insan manusia juga

${ }^{1}$ Prasetyo, W. A. (2016). Kinerja Forum Pelaksana Tanggungjawab Sosial Perusahaan (FP-TSP) Dalam Melaksanakan Program Corporate Social Responsibility (CSR) Di Kabupaten Kulon Progo. Adinegara, 5(5). 


\section{$\mathcal{H}$ urnal Negara dan Keadilan \\ p-ISSN 2302-7010 e-ISSN 2721-9801}

memliki peran untuk mewujudkan kesejahteraan sosial dan pengelolaan kualitas hidup masyarakat.

Salah satu kunci hadirnya program TJSL adalah isu mengenai pentingnya hubungan yang harmonis antara pemangku kepentingan (stakeholders), serta pihak perusahaan itu sendiri (shareholders). Stakeholders yang dimaksud adalah pihak yang berkepentingan terhadap keberadaan perusahaan yang mempengaruhi pengambilan keputusan dan kebijakan perusahaan yang akan diterapkan serta pihak-pihak yang terkait dampak operasional perusahaan. ${ }^{2}$

Menanggapi permasalahan tersebut maka serta dalam rangka meningkatkan kesejahteraan masyarakat dengan melibatkan seluruh perusahaan yang beroperasi di wilayah Kabupaten Probolinggo pada khususnya, maka pemerintah Kabupaten Probolinggo mengeluarkan Peraturah Daerah Kabupaten Probolinggo Nomor 1 Tahun 2014 tentang Pelaksanaan Program Tanggungjawab Sosial dan Lingkungan Perusahaan, serta Peraturan Bupati Probolinggo Nomor 88 Tahun 2017 tentang Petunjuk Teknis Pelaksanaan Program Tanggungjawab Sosial dan Lingkungan Perusahaan.

Dikeluarkannya kedua peraturan daerah tersebut bertujuan untuk memberikan arah, kebijakan dan kepastian hukum dan perlindungan hukum bagi dunia usaha atas pelaksanaan Program TJSL secara terpadu dan berdaya guna dalam menciptakan hubungan yang serasi, seimbang, dan sesuai dengan lingkungan, nilai, norma, dan budaya masyarakat di daerah, melalui upaya memperbaiki kualitas hidup masyarakat serta memperbaiki kualitas lingkungan hidup dan ekosistem sehingga menciptakan pembangunan berkelanjutan, melindungi perusahaan agar terhindar dari pungutan liar yang dilakukan oleh pihak-pihak yang tidak berwenang.

Dengan dikeluarkannya peraturan tingkat daerah di atas pula maka hal ini menunjukkan pemerintah Kabupaten Probolinggo melegitimasi keberadaan Forum Komunikasi Tanggungjawab Sosial Perusahaan yang kemudian disingkat menjadi FKTSP Kabupaten Probolinggo. Hal ini dikarenakan bahwa FKTSP Kabupaten Probolinggo telah didirikan pada tahun 2012 oleh sejumlah perusahaan yang telah sekian lama berperan aktif dalam pelaksanaan program tanggung jawab sosial dan lingkungan perusahaan di Kabupaten Probolinggo.

FKTSP Kabupaten Probolinggo bersifat independen dan tidak menjadi alat bagi pemerintah atau kepentingan politik (subordinasi) namun dapat menjadi mitra kerja pemerintah daerah dalam pelaksanaan pembangunan di bidang ekonomi dan sosial.

FKTSP ini merupakan wadah bagi perusahaan-perusahaan di Kabupaten Probolinggo dalam melaksanakan program tanggungjawab sosial dan lingkungan perusahaannya.

Berdasarkan latar belakang tersebut maka tujuan dari penelitian ini adalah Menjelaskan peran, fungsi dan tanggungjawab FKTSP Kabupaten Probolinggo dalam pelaksanaan program tanggungjawab sosial dan lingkungan perusahaan. Selain itu menjelaskan faktor-faktor pendukung dan penghambat bagi FKTSP

2 Disemadi, Hari Sutra, and Paramita Prananingtyas. "Kebijakan Corporate Social Responsibility (CSR) sebagai Strategi Hukum dalam Pemberdayaan Masyarakat di Indonesia." Jurnal Wawasan Yuridika 4.1 (2020): 1-16. 


\section{Zurnal Negara dan $\mathcal{X}$ eadilan \\ p-ISSN 2302-7010 e-ISSN 2721-9801}

Kabupaten Probolinggo dalam pelaksanaan program tanggungjawab sosial dan lingkungan perusahaan.

Berdasarkan permasalahan yang menjadi fokus kajian dalam penelitian ini serta tujuan yang ingin dicapai, diharapkan penelitian ini dapat memberikan manfaat Secara teoritis hasil dari penelitian ini diharapkan dapat memberikan sumbangan pemikiran bagi pengembangan ilmu hukum pada umumnya dan hukum pemerintahan daerah Kabupaten Probolinggo khususnya terutama dalam implementasi program tanggungjawab sosial dan lingkungan perusahaan, dan juga dapat menjadi bahan referensi kepustakaan bagi pembaca yang ingin melakukan pengembangan penelitian lebih lanjut dalam pokok permasalahan yang sama.

\section{METODE PENELITIAN}

Penelitian ini merupakan jenis penelitian hukum-empiris dengan pendekatan deskriptif kualitatif dan bersifat eksploratoris. Subjek penelitian ini adalah Kabag Perekonomian Bappeda Kabupaten Probolinggo, dilanjutkan dengan Ketua FKTSP Kabupaten Probolinggo, serta Unit Pelaksana CSR PT POMI Kabupaten Probolinggo sebagai salah satu perwakilan perusahaan pelaksanan program TJSL.

Untuk sumber data, dalam penelitian ini peneliti menggunakan 2 sumber data, yaitu sumber data primer berupa hasil wawancara dan observasi sementara sumber data sekunder yang diantaranya perundang-undangan tentang TJSL, dokumen, laporan FKTSP Kab Probolinggo dan lain sebagainya. Lebih lanjut untuk teknik pengumpulan yang digunakan adalah wawancara, observasi lapangan, dan dokumentasi. Analisis data penelitian menggunakan tiga tahap yaitu, reduksi data, penyajian data dan penarikan kesimpulan/verifikasi. Dan terakhir untuk pengujian keabsahan data dengan menggunakan teknik triangulasi sumber.

\section{PEMBAHASAN}

FKTSP adalah sebuah forum komunikasi yang didirikan oleh sejumlah perusahaan pelaksanan program TJSL yang benar-benar bersifat independen yang mana fungsi pembentukan FKTSP ini adalah sebagai wadah bagi perusahaan penyelenggara TJSL untuk berinteraksi (saling berkomunikasi, berdiskusi, bersosialisasi) dan mengintegrasikan seluruh kepentingan dalam menyelenggarakan program TJSL agar pelaksanaannya tepat sasaran dan tepat manfaat. ${ }^{3}$

FKTSP yang didirikan pada tanggal 17 Juli 2012 ini merupakan Forum TJSL pertama yang ada di wilayah Jawa Timur. Hal ini sebagaimana penjelasan Bapak Sugeng bahwa, Berdirinya FKTSP ini berawal dari peristiwa Erupsi Gunung Bromo pada tahun 2010, dimana dampak dari bencana alam tersebut selain berdampak pada kerusakan infrastruktur juga mengakibatkan rusaknya lahan pertanian di sekitaran Gunung Bromo, sehingga tidak sedikit perusahaan yang kemudian mengambil peran dalam upaya

\footnotetext{
3 Rochayatun, S., \& Handayati, P. (2019). Analisis Pengembangan Kelembagaan Forum Corpo-Rate Social Responsibilitydi Jawa Timur. Jurnal Akuntansi Aktual, 3(4), 290-301.
} 


\section{Jurnal Negara dan $\mathcal{X}$ eadilan \\ p-ISSN 2302-7010 e-ISSN 2721-9801}

menyelamatkan masyarakat sebagai terdampak dari erupsi tersebut dan membantu upaya pemulihan kondisi perekonomian yang berkelanjutan.

Berangkat dari pelaksanaan program tersebut kemudian munculah sebuah ide untuk membentuk semacam forum komunikasi diantara perusahaan agar kedepannya dalam pelaksanaan TJSL bisa terlaksana dengan lebih terorganisir dan menjadi penghubung antara pihak perusahaan dengan pemerintah daerah Kabupaten Probolinggo.

Hingga tahun 2020 tercatat bahwa anggota FKTSP Kabupaten Probolinggo berjumlah 21 perusahaan yang terdiri dari berbagai jenis perusahaan,

\section{Peran, Fungsi dan Tanggungjawab FKTSP}

Program TJSL di wilayah Kabupaten Probolinggo sejatinya telah lama dilaksanakan oleh setiap perusahaan sebagaimana yang telah diamanatkan dalam undangundang perseroan terbatas. Hanya saja dalam pelaksanaannya belum terencana dengan matang, belum terorganisir dengan baik, dan pemerintah daerah sebagai pemegang kekuasaan eksekutif belum terlibat dengan maksimal.

Atas dasar inilah kemudian sejumlah perusahaan membentuk FKTSP sebagai wadah bagi perusahaan penyelenggara TJSL untuk saling berinteraksi (saling berkomunikasi, berdiskusi, bersosialisasi) dan mengintegrasikan seluruh kepentingan dalam menyelenggarakan program TJSL agar pelaksanaannya tepat sasaran dan tepat manfaat.

Hal ini sebagaimana penjelasan Ibu Nina Ari Wahyuni bahwa, Dengan adanya FKTSP ini kami jadi lebih terbantu dalam melaksanakan program CSR ini mas. Ada beberapa perusahaan yang sebenarnya memiliki potensi dan kemampuan untuk melakukan program TJSL di luar wilayah Kabupaten Probolinggo, hanya saja terikat oleh peraturan hukum (internal perusahaan) yang membatasi jangkauan wilayahnya. Sehingga FKTSP Kabupaten Probolinggo berperan dalam membangun jejaring dengan mitra strategis. Selain itu juga FKTSP Kabupaten Probolinggo juga bermanfaat untuk memfilter segala program yang telah ditentukan oleh pemerintah agar tidak terjadi tumpang tindih dengan program TJSL perusahaan lainnya.

Lebih lanjut peneliti akan memaparkan tentang bagaimana peran, fungsi dan tanggungjawab FKTSP Kabupaten Probolinggo disetiap tahapan pelaksanaan program TJSL sebagai wadah komunikasi dan koordinasi perusahaan-perusahaan terebut.

\section{Tahap Perencanaan}

Dalam tahap perencanaan, salah satu permasalahan yang pada awalnya muncul adalah tentang wilayah dan/atau batas wilayah diperbolehkannya pelaksanaan porgram TJSL oleh masing-masing perusahaan. Sebagaimana gambar diagram berikut bahwa.

Gambar 1. Jangkauan Program TJSL Perusahaan

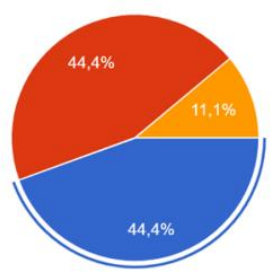

- Lintas wilayah Kab./Kota

- Wilayah sekitar perusahaan di Kab.

Kota yang sama

- Lingkungan internal perusahaan

Sumber :

Laporan Ketua FKTSP dalam pelasanaan CSR Award pada tahun 2019 


\section{Hurnal Negara dan $\mathcal{X}$ eadilan \\ p-ISSN 2302-7010 e-ISSN 2721-9801}

Tidak sedikit perusahaan besar yang beroperasi di Kabupaten Probolinggo, sehingga dengan "kemampuan" yang dimilikinya maka sewajarnya wilayah pelaksanaan program TJSLnya perusahaan cukup luas, bahkan keluar dari wilayah Kabupaten Probolinggo.

Pada tahapan perencanaan, pemerintah daerah setiap awal tahun melaksanakan musyawarah rencana pembangunan (Musyrenbang) dengan melibatkan seluruh stakeholder. Hanya saja dari hasil pelaksanaan musyrenbang tidak seluruhnya diajukan ke FKTSP, hal ini sebagaimana penjelasana Bapak Anis Yahya bahwa, Tidak seluruh hasil musyrenbang atau usulan yang telah dihasilkan kemudian disampaikan ke FKTSP, karena Bappeda juga perlu melakukan verifikasi dan validasi terhadap berbagai program yang telah diusulkan oleh pihak desa. Karena terkadang usulan yang diajukan oleh masyarakat juga hanya sekedar usulan, tanpa ada perencanaan yang matang.

Kemudian pada tahapan perencanaan FKTSP Kabupaten Probolinggo berperan sebagai koordinator dan fasilitator yang tidak dapat mengintervensi perusahaan dalam mengabil keputusan, sementara untuk penentuan perusahaan mana yang akan melaksanakan dan program TJSL seperti apa yang akan dilaksanakan itu diserahkan kembali ke perusahaan.

\section{Tahap Pelaksanaan}

Pada tahap pelaksanaan FKTSP tidak memiliki peranan yang besar, karena program TJSL yang dilaksanakan sepenuhnya diserahkan kembali kepada perusahaan. Sesuai dengan kemampuan dan perencanaan yang telah ditetapkan oleh perusahaan tersebut.

Hal ini sesuai dengan penjelasan Bapak Sugeng bahwa, Dalam pelaksanaan TJSL tetap perusahaan masing-masing yang melaksanakan, sementara forum ini hanya mengkordinir, saya itu berkoordinasinya dengan Bappeda. Begitupun dengan Bappeda, Jadi Bappeda itu setelah menampung aspirasi dari masyarakat barulah berkoordinasi dengan saya.

Penjelasan Ketua FKTSP tersebut kemudian didukung dengan laporan pada tahun 2019 yang menunjukkan bahwa pada tahap pelaksanaan ini, banyak perusahaan yang melakukan koordnasi langsung dengan Bappeda Kabupaten Probolinggo Sebagaimana diagram berikut.

Gambar 3. Koordinasi Perusahaan dalam Pelaksanaan Progam dengan Pemerintah Daerah
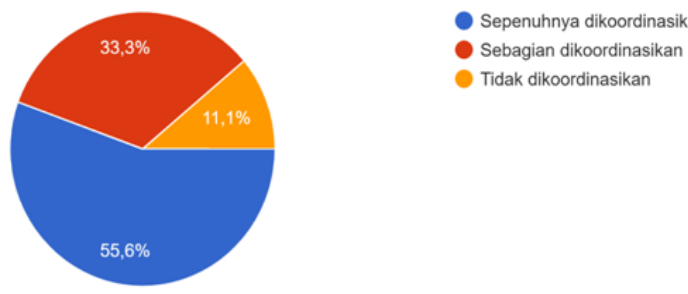

- Tidak dikoordinasikan

Sumber :

Laporan Ketua FKTSP Kabupaten Probolinggo dalam CSR Award pada tahun 2019

Tahap Monitoring dan Evaluasi

Pada tahapan ini berdasarkan hasil wawancara dan Laporan Ketua FKTSP dapat diketahui sebagimana diagram berikut

Gambar 2. Pelaksanaan Monev Program TJSL FKTSP Kab Probolinggo 


\section{Jurnal Negara dan $\mathcal{X}$ eadilan \\ p-ISSN 2302-7010 e-ISSN 2721-9801}
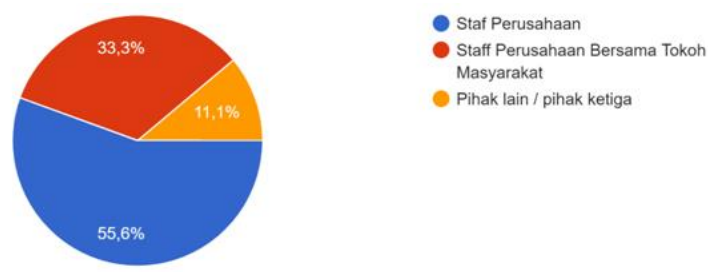

Masyarakat

- Pihak lain / pihak ketiga

Sumber :

Laporan Ketua FKTSP Kabupaten Probolinggo dalam CSR Award pada tahun 2019 berikut.

Secara rinci gambaran tentang proses monitoring yang dilakukan adalah sebagai

Bahwa Ada dua metode yang digunakan oleh pihak pemerintah daerah untuk melakukan tahapan monitoring jalannya program TJSL. Pertama dengan metode monitoring langsung ke lokasi pelaksanaan program TJSL. Hal ini dilakukan dengan melibatkan Forum Komunikasi Pimpinnan di setiap desa atau kecamatan tempat pelaksanaan program TJSL. Sementara metode kedua yaitu pelaporan, yang dilakukan secara berkala oleh masing-masing perusahaan melalui FKTSP dan disinilah peran FKTSP dalam monitoring. FKTSP mengaudit dan memverifikasi setiap laporan yang diberikan oleh perusahaan sebelum diserahkan kepada pemerintah daerah. Hal ini sebagaimana penjelasan dari Bapak Anis Yahya bahwa, Monitoring dan evaluasi pelaksanaan program TJSL yang selama ini kami laksanakan dengan menggunakan dua metode. Pertama yaitu melalui metode pelaporan oleh pihak perusahaan dan stakeholder dimana memang metode ini yang sering kami gunakan. Kedua, dengan menggunakan metode monitoring langsung ke lokasi yang dilakukan dengan melibatkan pihak perusahaan, pemerintah di tingkat kecamatan dan desa lokasi pelaksanaan program TJSL.

Lain halnya dengan apa yang dilaporkan oleh Ketua FKTSP. Dimana dalam pelaksanaan monitoring dan evaluasi beberapa perusahaan juga melibatkan pihak ketiga. Hal ini dilakukan agar hasil yang diberikan lebih akuntabel.

Program TJSL Perusahaan di Kabupaten Probolinggo

Gambar 4. Jenis program TJSL

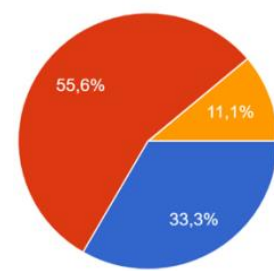

- Rehabilitasi sosial, pemberdayaan

sosial, perlindungan sosial, dan

2-3 jenis program

Sumber :

Laporan Ketua FKTSP Kabupaten Probolinggo dalam CSR Award pada tahun 2019

Diagram di atas menjelaskan bahwa berbagai jenis program TJSL yang selama ini telah dilakukan oleh perusahaan. Dan hal ini tidaklah salah mengingat program-progam yang dilakukan memang sudah disesuaika dengan kemampuan perusahaan dan kebutuhan masyarakat terutama di lingkungan sekitar perusahaan.

Hanya saja dalam penyusunan program TJSL di Kabupaten Probolinggo sebagaimana yang telah diamanatkan dalam Pasal 4 Ayat (2) Peraturan Daerah Nomor 1 Tahun 2014 bahwa kegiatan TJSL di wilayah Kabupaten Probolinggo harus diselaraskan dengan agenda prioritas pembangunan daerah, sehingga untuk program kegiatan TJSL ini dapat diklasifikasikan sebagaimana berikut: Program kegiatan di bidang pendidikan, kesehatan, infrastruktur, lingkungan hidup, sosial dan budaya serta program kegiatan di bidang olahraga. 


\section{Hurnal Negara dan $\mathcal{X}$ eadilan \\ p-ISSN 2302-7010 e-ISSN 2721-9801}

\section{Faktor pendukung program TJSL di Kabupaten Probolinggo}

a. Semangat dan komitmen perusahaan anggota FKTSP

Jauh sebelum Peraturan Daerah dan Peraturan Bupati Probolinggo yang mengatur tentang pelaksanaan TJSL disahkan, eksistensi perusahaan-perusahaan di Kabupaten Probolinggo dalam melaksanakan program TJSL-nya tidak perlu diragukan lagi. Bahkan terbentuknya FKTSP Kabupaten Probolinggo telah mendahului lahirnya kedua landasan hukum tersebut.

b. $\quad$ Instrumen hukum yang memadai

Semenjak dikeluarkannya dua peraturan di tingkat daerah Kabupaten Probolinggo, semenjak itu pula kegiatan TJSL yang digagas oleh berbagai perusahaan terlihat lebih baik dan terintegrasi dalam pengelolaannya.

Kedua peraturan daerah tersebut juga telah memberikan penjelasan tentang tahapan-tahapan pengelolaan pelaksanaan TJSL dan sanksi yang tegas bagi perusahaan yang tidak melaksanakan program TSP.

c. Kemajuan teknologi dan informasi

Tidak bisa dipungkiri bahwa saat ini kita telah memasuki era Revolusi Industri 4.0. Dimana inovasi dan kreatifitas menjadi tuntutan tersendiri bagi setiap perusahaan dalam mengahdapi persaingan global.

Dengan kemajuan teknologi dan informasi ini segala program kegiatan TSP yang telah direncanakan dapat terlaksanan dengan lebih efektif. Upaya Sinergitas antar pihak penyelenggara program TSP-pun dapat terlaksana dengan baik

d. Kesadaran masyarakat

Semangat masyarakat untuk meningkatkan kualitas hidup dengan tetap memperhatikan kondisi lingkungan maerupakan salah satu faktor pendukung yang tak dapat dipungkiri. Hal ini disebabkan bahwa salah tujuan dari pelaksanaan dan peneriman manfaat terbesar dari program TJSL ini adalah masyarakat dan lingkungan yang sifatnya berkelanjutan

\section{Faktor penghambat program TJSL di Kabupaten Probolinggo}

a. Adanya peraturan internal perusahaan yang berbenturan dengan Perda Kabupaten Probolinggo

Aturan dan kondisi sebagian perusahaan yang dinilai kurang fleksibel menjadi salah satu faktor penghambat dalam pelaksanaan program TJSL di Kabupaten Probolinggo.

Hal ini sesuai dengan apa yang disampaikan oleh Ibu Nina Ari Wahyuni bahwa, "Terkadang ada beberapa perusahaan yang memang memiliki peraturan tertentu dalam pelaksanaan TJSL yang malah menjadi penghambat, misalkan berkaitan dengan lokasi pelaksanaan program TJSL

b. Belum adanya SOP dan indikator yang lebih rinci tentang proses kerja FKTSP Kabupaten Probolinggo

Sebagai sebuah badan hukum yang berkewajiban mengkordinir dan memfasilitasi jalannya pelaksanaan program TJSL tentunya SOP menjadi sebuah kebutuhan yang mendasar agar setiap langkah yang dilakukan tetap selaras dengan visi dan misinya.

c. Dukungan secara teknis oleh pemerintah daerah

Ada dua alasan yang kemudian oleh penulis memasukan dukungan dari pemerintah daerah menjadi faktor penghambat. Pertama, ketiadaannya tim fasilitasi sebagai mitra FKTSP dalam melaksanakan program TJSL di Kabupaten Probolinggo sebagaimana yang telah diamanatkan dalam Perbup Nomor 88 Tahun 2017

Kedua, pada tahapan monitoring dan evaluasi dimana munculnya kesan bahwa pemerintah daerah seolah-olah hanya menunggu laporan dari pihak perusahaan dalam pelaksanaan program TJSL-nya, terutama pada masa pandemi, padahal dalam hal ini pemerintah daerah dapat mengambil peranan yang lebih penting terutama.

d. Pandemi Covit-19 yang berdampak pada sejumlah perusahaan 


\section{Jurnal Negara dan $\mathcal{X}$ eadilan \\ p-ISSN 2302-7010 e-ISSN 2721-9801}

Tidak sedikit perusahaan yang terdampak oleh pandemi Covid-19 dan dampak dari pandemi ini diantaranya. Pertama pengalihan alokasi dana perusahaan yang kemudian digunakan untuk mengahadapi penyebaran Virus Covid-19; Kedua, Perubahan tata kelola dan Standar Operasional Prosedur yang disesuaikan dengan protokol kesehatan. Ketiga, Perubahan bentuk kegiatan dari yang semula dilaksanakan secara offline, kemudian lebih sering dilaksanakan dengan berbasis internet.

Hanya saja, lain halnya dengan apa yang disampaikan oleh ibu Nina Ari Wahyuni yang menjelaskan bahwa, Lambat waktu kita memang harus bisa bersahabat dengan kondisi pandemi ini. Kita berusahan mencari peluang yang ada agar program-program TJSL ini dapat tetap terlaksana.

e. Mindset Masyarakat.

Walaupun pada bagian faktor pendukung telah penulis masukkan unsur semangat masyarakat dalam upaya meningkatkan kesejahteraan hidup. Hanya saja pola pikir sebagian masyarakat menjadi ironi. Hal ini disebabkan masih banyaknya pola pikir masyarakat yang berangapan bahwa program TJSL ini sifatnya hanya berupa hibah, hadiah dan/atau bantuan Cuma-Cuma yang diberikan oleh pihak perusahaan layaknya Bantuan Langsung Tunai dari pemerintah. Dengan adanya pola pikir yang demikian jelas akan mempersulit upaya perusahaan untuk mencapai program TJSL yang berkelanjutan, memberdayakan dan memperhatikan kelanhgsungan lingkungan.

\section{PENUTUP}

Berdasarkan hasil penelitian dan pembahasan, maka dapat disimpulan bahwa:

1. Peran, fungsi dan tangungjawab dari FKTSP Kabupaten Probolinggo adalah:

a. Sebagai koordinator dan fasilitator yang bertugas menginventarisasi rencana program TJSL oleh perusahaan;

b. Menyelaraskan, sinkronisasi, harmonisasi dan integrasi program TJSL dengan usulan prioritas yang telah ditetapkan;

c. Melakukan monitoring dan evaluasi pelaksanaan program TJSL bersama Tim Fasilitasi.

2. Faktor pendukung program TJSL di Kabupaten Probolinggo diantaranya

a. Semangat dan komitmen perusahaan anggota FKTSP

b. Instrumen hukum yang memadai

c. Kemajuan teknologi dan informasi

d. Kesadaran masyarakat

3. Faktor penghambat program TJSL di Kabupaten Probolinggo diantaranya

a. Adanya peraturan internal perusahaan yang berbenturan dengan Perda Kabupaten Probolinggo

b. Belum adanya SOP dan indikator yang lebih rinci tentang proses kerja FKTSP Kabupaten Probolinggo

c. Dukungan secara teknis oleh pemerintah daerah

d. Pandemi Covit-19 yang berdampak pada sejumlah perusahaan

e. Mindset Masyarakat yang masih beranggapan bahwa program TJSL hanya berupa hibah, hadiah dan/atau bantuan Cuma-Cuma.

\section{Perundang-undangan}

\section{DAFTAR PUSTAKA}

Undang-undang Nomor 40 Tahun 2007 tentang Perseroan Terbatas Undang-undang Nomor 25 Tahun 2007 tentang Penanaman Modal

Peraturan Pemerintah Nomor 47 Tahun 2012 tentang Tanggung Jawab Sosial dan Linkungan Perseroan Terbatas 


\section{$\mathcal{H}$ urnal Negara dan $\mathcal{X}$ eadilan \\ p-ISSN 2302-7010 e-ISSN 2721-9801}

Peraturan Daerah Kabupaten Probolinggo Nomor 1 Tahun 2014 tentang Pelaksanaan Program Tangungjawab Sosial dan Lingkungan Perusahaan

Peraturan Bupati Probolinggo Nomor 88 Tahun 2017 tentang Petunjuk Teknis Pelaksanaan Peraturan Daerah Nomor 1 Tahun 2014 Tentang Pelaksanaan Program Tanggungjawab Sosial dan Lingkungan Perusahaan

\section{Jurnal Ilmiah}

Prasetyo, W. A. (2016). Kinerja Forum Pelaksana Tanggungjawab Sosial Perusahaan (FP-TSP) Dalam Melaksanakan Program Corporate Social Responsibility (CSR) Di Kabupaten Kulon Progo. Adinegara, 5(5).

Rochayatun, S., \& Handayati, P. (2019). Analisis Pengembangan Kelembagaan Forum Corpo-Rate Social Responsibilitydi Jawa Timur. Jurnal Akuntansi Aktual, 3(4), 290-301.

Disemadi, Hari Sutra, and Paramita Prananingtyas. 2020. Kebijakan Corporate Social Responsibility (CSR) sebagai Strategi Hukum dalam Pemberdayaan Masyarakat di Indonesia. Jurnal Wawasan Yuridika 4.1 